DOI: 10.46340/eppd.2021.8.1.9

Tetyana Grabovich, PhD in Law

ORCID ID: https://orcid.org/0000-0001-6819-0486

Vinnytsia, Ukraine

\title{
STATE RESPONSIBILITY IN THE SPHERE OF THE USE OF SPACE
}

Тетяна Грабович, к. ю. н.

Вінниця, Україна

\section{ВІДПОВІДАЛЬНІСТЬ ДЕРЖАВИ \\ У СФЕРІ ВИКОРИСТАННЯ КОСМІЧНОГО ПРОСТОРУ}

The article examines the problem of responsibility of states in outer space. The role of the UN in the formation of standards of international legal regulation of the state responsibility in the international space law is determined. The provisions on the responsibility of states enshrined in the Declaration of Legal Principles Governing the Activities of States in the Exploration and Use of Outer Space (1963), the Treaty on Principles Governing the Activities of States in the Exploration and Use of Outer Space, including the Moon and Other Celestial Bodies (1967), the Convention on International Liability for Damage Caused by Space Objects (1972) are analyzed. The essence of the principle of absolute liability for damage caused by lawful activities of the state in the use of outer space and cases of deviation from this principle are revealed. It is established that the implementation of responsibility in international space law is based on the system of its guarantee. It is concluded that it is necessary to maintain a balance between the development of commercial space activities and the activities of states in the exploration and use of outer space to ensure the interests of mankind as a whole. The existence of certain roughnesses of the regime of responsibility of states in outer space has been established with the provisions of international environmental law, in particular, on the possibility of claiming compensation for serious damage to the environment as a result of space activities, and not only for damage caused to the property of the state or its citizens. The need to consolidate preventive measures to prevent harm caused by space activities was determined, as well as the need to use effective mechanisms for resolving possible disputes in the field of the use of outer space with the participation of various actors.

Keywords: international responsibility of states, use of outer space, launching state, absolute responsibility, outer space.

У сучасних умовах прискорення темпів науково-технічного прогресу у сфері космічної діяльності виникають, розвиваються і формуються нові види космічних відносин, які потребують належного правового врегулювання. Одночасно істотних змін зазнає комплекс космічно-правових відносин, пов'язаних з дослідженням і використанням космічного простору та небесних тіл. У зв'язку 3 цим великого значення набуває пошук нових можливих напрямів та удосконалення наявних способів вирішення актуальних космічно-правових питань 3 метою забезпечення прогресивного розвитку міжнародного та національного космічного права ${ }^{1}$.

Головною рисою сучасної космічної діяльності $є$ ії активна комерціалізація. Збільшення числа неурядових учасників космічної діяльності, створення і впровадження нових передових технологій в космічній промисловості стимулюють зростання конкуренції на світових космічних ринках. Основною метою дослідження і використання космосу стає одержання прибутку. Поступальний розвиток космічної діяльності протягом більш ніж півстоліття забезпечувався стабільним всеосяжним

\footnotetext{
${ }^{1}$ Шемшученко, Ю. С., Семеняка, В. В. (2014). Делімітація повітряного і космічного просторів: основні теоретичні проблеми та практика. Вісник Національної академії наук Украӥни, 11, 18.
} 
міжнародно-правовим режимом, фундаментом якого є Договір про принципи діяльності держав з дослідження і використання космічного простору, включаючи Місяць і інші небесні тіла 1967 р. (далі - Договір 3 космосу). Оскільки космічна діяльність історично формувалася зусиллями суверенних держав, норми Договору з космосу та інших міжнародних договорів, прийнятих в розвиток окремих його положень, в повній мірі забезпечували належну міжурядову співпрацю. Однак процеси комерціалізації космічної діяльності зумовили появу нової категорії учасників космічних операцій - комерційних організацій, що вимагає відповідних змін і в міжнародному космічному праві. 3 огляду на те, що комерційні оператори з кожним роком займають все більш міцні позиції на світових космічних ринках, фактично витісняючи держави, такі нові гравці зацікавлені у всебічному і ефективному правовому захисті своїх інтересів - який чинне міжнародне космічне право їм забезпечити не може. Як свідчить практика, проблема міжнародної відповідальності держав за національну космічну діяльність, в тому числі здійснювану комерційними організаціями, є однією 3 ключових у міжнародному космічному праві i в зв'язку з цим вимагає першорядної уваги ${ }^{1}$. Представлена стаття спрямована на вивчення особливостей режиму міжнародної відповідальності у сфері використання космічного простору.

Питання відповідальності за здійснення діяльності у сфері міжнародного космічного права порушувалися у низці праць, зокрема такими вченими як Блищенко І. П., Волинська О. О., Жуков Г. П., Колосов Ю. М., Малков С. П., Матіас Ф., Сидорова Т. Ю. та ін., водночас проблема міжнародноправової відповідальності у сфері використання космічного простору потребує свого подальшого грунтовного дослідження з урахуванням сучасних реалій.

Оскільки проблеми космосу тісно переплетені з інтересами держав у військовій, політичній та інших областях, вони стали предметом обговорення в рамках $\mathrm{OOH}^{2}$. У 1962 р. Генеральна Асамблея $\mathrm{OOH}$ через Комітет ООН з мирного використання космічного простору (COPUOS), почала розглядати питання про розробку режиму відповідальності у космічному просторі, враховуючи тяжкість шкоди, яка може бути заподіяна внаслідок діяльності у цій сфері ${ }^{3}$. Так, у резолюції 1802 (XVII) від 1962 р. ГА ООН «Міжнародне співробітництво у використанні космічного простору в мирних цілях» відзначила необхідність продовжувати зусилля щодо подальшої розробки основних правових принципів діяльності держав щодо дослідження та використання космічного простору і питань про відповідальність за шкоду, заподіяну в результаті нещасних випадків з космічними кораблями, наданні допомоги і повернення космонавтів і космічних кораблів та інших правових проблем ${ }^{4}$. ГА ООН у 1963 році прийняла «Декларацію правових принципів, що регулюють діяльність держав по дослідженню і використанню космічного простору».

3 часом почала виокреслюватися потреба у забезпеченні балансу між мирним використанням космічного простору та необхідністю відшкодування шкоди, яку таке використання може спричинити. Договір про принципи діяльності держав по дослідженню і використанню космічного простору, включаючи Місяць та інші небесні тіла 1967 (далі - Договір про космос) є прикладом гарантування такого балансу. Цей документ поєднує твердження щодо свободи відкритого дослідження і використання всіма державами космічного простору (ст. I) та принципу міжнародної відповідальності за шкоду, яку запущені у космічний простір об'єкти спричинили на Землі, у повітряному або в космічному просторі (ст. VII).

Інший документ - Конвенція про міжнародну відповідальність за шкоду, завдану космічними об’єктами 1972 р. (далі - Конвенція про відповідальність), твердження про відповідальність конкретизувала. Ця Конвенція є стрижнем у космічному праві стосовно режиму відповідальності ${ }^{5}$.

Конвенція про відповідальність розкриває положення статті VII Договору з космосу, зокрема, розмежовуючи відповідальність за шкоду в космосі і поза його межами, а також закріплюючи

\footnotetext{
${ }^{1}$ Волынская, О. А. (2014). Международно-правовые аспекты ответственности в области космической деятельности: диссертация на соискание научной степени кандидата юридических наук. Москва: Российский университет дружбы народов, 3-4.

${ }^{2}$ Удалов, Д. Э. (2011). Международное космическое право. Научный вестник МГИИТ, 3, 91.

${ }^{3}$ Forteau, M. (2010). Space Law. In Crawford J., Pellet A. and Olleson S. (eds.). The Law of International Responsibility. Oxford: Oxford University Press, 903.

${ }^{4}$ Межндународное сотрудничество в использовании космического пространства в мирных иелях, 1962 (ГА ООН). 1802 (XVII). 1192-е пленарное заседание. UN Doc. A/RES/1802 (XVII).

${ }^{5}$ Forteau, M. (2010). Space Law. In Crawford J., Pellet A. and Olleson S. (eds.). The Law of International Responsibility. Oxford: Oxford University Press, 904.
} 
особливий міжнародно-правовий механізм врегулювання суперечок, що виникають у зв'язку з заподіянням шкоди ${ }^{1}$.

3 огляду на те, що космічна діяльність може завдати значної шкоди як окремим державам i приватним особам під їх юрисдикцією, так і людству в цілому, була вироблена унікальна для міжнародного космічного права формула: держави несуть відповідальність за всю національну діяльність в космосі, включаючи дії (бездіяльність) своїх урядових органів і неурядових осіб. Дане положення було вперше закріплено в Декларації правових принципів, що регулюють діяльність держав по дослідженню і використанню космічного простору 1963 р. (п. 5, п. 8)².

У ст. VI Договору з космосу закріплено: «Держави-учасниці Договору несуть міжнародну відповідальність за національну діяльність у космічному просторі, включаючи Місяць та інші небесні тіла, незалежно від того, провадиться вона урядовими органами чи неурядовими юридичними особами, і за забезпечення того, щоб національна діяльність провадилася згідно з положеннями, що містяться в цьому Договорі. Діяльність неурядових юридичних осіб у космічному просторі, включаючи Місяць та інші небесні тіла, має провадитися з дозволу і під постійним спостереженням відповідної держави - учасниці Договору. У випадку діяльності в космічному просторі, включаючи Місяць та інші небесні тіла, міжнародної організації, відповідальність за виконання цього Договору несуть, разом з міжнародною організацією, також і держави, що беруть у ній участь».

Вже згадувана стаття VII Договору 3 космосу встановлює, що «Кожна держава-учасниця Договору, яка здійснює або організує запуск об’єкта в космічний простір, включаючи Місяць та інші небесні тіла, а також кожна держава-учасниця Договору, з території або установок якої здійснюється запуск об'єкта, несе міжнародну відповідальність за шкоду, завдану такими об'єктами або їх складовими частинами на Землі, у повітряному або в космічному просторі, включаючи Місяць та інші небесні тіла, іншій державі-учасниці Договору, ії фізичним або юридичним особам».

Виходячи зі змісту статей VI і VII Договору з космосу, відповідальність може бути наслідком шкоди, викликаної діями не тільки самої держави (в особі ії органів), але також і неурядових осіб. Тим самим, міжнародно-правові наслідки такої шкоди, а саме обов'язок відшкодувати завдану шкоду, в повній мірі $є$ тягарем відповідної держави. Ця позиція підтверджується при аналізі практичної застосовності зазначених статей Договору з космосу і отримала широку підтримку в міжнародноправової літературі ${ }^{3}$.

Стаття II Конвенції про відповідальність закріплює, що держава, яка здійснює запуск, несе абсолютну відповідальність за виплату компенсації за шкоду, заподіяну іiї космічним об'єктом на поверхні Землі або повітряному судну в польоті. Компенсація, яку запускаюча держава зобов'язана виплатити на підставі цієї Конвенції за завдану шкоду, визначається відповідно до міжнародного права і принципів справедливості, з тим щоб забезпечити відшкодування шкоди, що відновлювало б фізичній або юридичній особі, державі або міжнародній організації, від імені яких подається претензія, положення, яке існувало б, якби шкоди не було завдано (ст. XII Конвенції про відповідальність).

Принцип абсолютної відповідальності за шкоду, відповідно до якого постраждала сторона не зобов'язана доводити вину заподіювача шкоди, був вироблений в міжнародному повітряному, морському, атомному праві у відповідь на розвиток технологій і зростаючі ризики в зв'язку з їх використання ${ }^{4}$.

Стаття III Конвенції про відповідальність передбачає відступ від принципу абсолютної відповідальності, закріплюючи, що у випадку, якщо в будь-якому місці, окрім поверхні Землі, космічному об'єкту однієї запускаючої держави або особам або майну на борту такого космічного об’єкта завдано шкоди космічним об'єктом іншої запускаючої держави, то остання

\footnotetext{
${ }^{1}$ Волынская, О. А. (2014). Международно-правовые аспекты ответственности в области космической деятельности: диссертация на соискание научной степени кандидата юридических наук. Москва: Российский университет дружбы народов, 39.

2 Декларации правовых принципов, регулирующих деятельность государств по исследованию и использованию космического пространства (ГА ООН). UN Doc. RES 1962 (ХVIII).

${ }^{3}$ Волынская, О. А. (2014). Международно-правовые аспекты ответственности в области космической деятельности: диссертация на соискание научной степени кандидата юридических наук. Москва: Российский университет дружбы народов, 38.

${ }^{4}$ Lachs, M. (2010). The Law of Outer Space: an Experience in Contemporary Law-Making. Edited by T. Masson-

Zwaan, S. Hobe. Leiden, Boston: Martinus Nijhoff Publishers, 115.
} 
несе відповідальність тільки у випадку, коли шкоди завдано з їі вини або з вини осіб, за яких вона відповідає.

Абсолютний режим відповідальності у космічному праві послаблюється також у випадку, передбаченому Статтею VI Конвенції про відповідальність, де відзначається, що звільнення від абсолютної відповідальності надається тією мірою, якою запускаюча держава доведе, що шкода стала повністю або частково результатом грубої недбалості або дії або бездіяльності вчинених з наміром завдати шкоди, з боку держави-позивача або фізичних або юридичних осіб, яких вона представляє.

Як вказує Матіас Форто, поява поняття «грубої» недбалості дещо дивує, оскільки воно відсутнє в загальних правилах про відповідальність за протиправні діяння в інших сферах міжнародного права ${ }^{1}$.

Далі у статті VI Конвенції про відповідальність відзначається, що жодного звільнення не надається у випадках, коли шкода стала результатом діяльності запускаючої держави, яка не відповідає міжнародному праву, включаючи, зокрема, Статут Організації Об'єднаних Націй і Договір про принципи діяльності держав по дослідженню і використанню космічного простору, включаючи Місяць та інші небесні тіла. У цьому випадку держава несе відповідальність внаслідок ії незаконного діяння, і державі не дозволяється звільнятись від цієї відповідальності за шкоду, якщо інша держава діяла необережно або брала участь у діях, які призвели до зазначеної шкоди. Відповідальність за шкоду існує в цьому випадку, адже наявна відповідальність за протиправне діяння.

Окремо слід звернути увагу на випадок, коли одному космічному об'єкту завдано шкоду другим космічним об'єктом з вини іншої держави. Питання вини вирішується Конвенцією про відповідальність в залежності від типів і видів правовідносин відповідальності. Згідно з Конвенцією, вина $€$ підставою відповідальності в двох випадках: коли один космічний об'єкт завдає шкоди іншому космічному об'єкту (або особам і майну на його борту); і коли шкода заподіяна третій державі, тобто коли один космічний об'єкт заподіює шкоду іншому і в результаті шкода виникла у третьої держави. Якщо правовідносини виникли в результаті заподіяння шкоди космічним об'єктом на поверхні Землі або повітряному судну в польоті, підставами відповідальності є тільки шкода і причинний зв'язок. Якщо ж правовідносини виникли внаслідок заподіяння шкоди одним космічним об'єктом іншому, то підставами відповідальності $є$ шкода, причинний зв'язок і вина²

Конвенція передбачає, що у випадку спільного запуску космічного об'єкта двома або більшою кількістю держав, вони несуть солідарну відповідальність за будь-яку завдану шкоду. Запускаюча держава, що виплатила компенсацію за шкоду, має право регресної вимоги до інших учасників спільного запуску. Учасники спільного запуску можуть укладати угоди про розподіл між собою фінансових зобов'язань, за якими вони несуть солідарну відповідальність. Такі угоди не зачіпають права держави, якій завдано шкоди, вимагати всієї компенсації за шкоду на основі Конвенції про відповідальність від будь-якої з запускаючих держав або всіх запускаючих держав, що несуть солідарну відповідальність (ст. V Конвенції про відповідальність).

Перейдемо до більш детальної характеристика поняття шкоди, яка підлягає відшкодуванню. Запускаюча держава є відповідальною оскільки запущений нею об'єкт спричинив шкоду.

Термін «космічний об'єкт» включає складові частини космічного об'єкта, а також засіб його доставки і його частини (ст. I Конвенції про відповідальність 1972 р.).

У Договорі з космосу визначення шкоди не дається. Під «шкодою» відповідно до ст. I Конвенції про відповідальність 1972 р. слід розуміти позбавлення життя, тілесне пошкодження або інше пошкодження здоров'я; або знищення або пошкодження майна держав, або фізичних або юридичних осіб, або майна міжнародних міжурядових організацій.

Отже відповідно до положень ст. I Конвенції шкода є наявною у разі:

- смерті людини;

- шкоди здоров'ю людини у вигляді тілесного ушкодження;

- іншої (тобто не пов'язаної з тілесним ушкодженням) шкоди здоров'ю людини;

- знищення майна держави, або фізичних або юридичних осіб, або майна міжнародних міжурядових організацій;

- пошкодження майна держави, або фізичних або юридичних осіб, або майна міжнародних міжурядових організацій.

\footnotetext{
${ }^{1}$ Forteau, M. (2010). Space Law. In Crawford J., Pellet A. and Olleson S. (eds.). The Law of International Responsibility. Oxford: Oxford University Press, 906.

${ }^{2}$ Малков, С. П. (2002). Международное космическое право. СПб: СПбГУАП, 164, 172.
} 
Цей перелік носить вичерпний і закритий характер. Якщо космічний об'єкт викличе наслідки, про які не йдеться в цьому списку, то і відповідальність не настає ${ }^{1}$.

Шкода життю та здоров’ю громадян (в тому числі моральна шкода), а також майну держав, організацій і осіб може бути прямою або опосередкованою. Згідно з Конвенцією про відповідальність шкода повинна бути заподіяна безпосередньо космічним об'єктом або його елементами, а не результатами його використання (обробленими космічними даними, отриманими в космосі матеріалами, технологіями і т.д.), тобто неодмінною умовою компенсації шкоди $\epsilon$ встановлення причинно-наслідкового зв'язку між шкідливою подією за участю космічного об'єкта і настанням несприятливих наслідків в кожному конкретному випадку. Відповідно, не дивлячись на відсутність в розглянутому визначенні космічного об'єкта вимоги причинно-наслідкового зв'язку між об'єктом і наступними несприятливими наслідками, така вимога презюмується виходячи 3 формулювання п. «а» ст. І Конвенції про відповідальність ${ }^{2}$.

На думку деяких авторів, наявне визначення шкоди потребує доповнення. На сьогоднішній день 3 огляду на загрозливі темпи зростання хімічного, біологічного, радіологічного засмічення космічного простору і атмосфери Землі конвенційне визначення потребує доопрацювання i включення в нього екологічної шкоди. Ця прогалина у визначенні була виявлена при міжнародноправовому аналізі першого в історії космонавтики міжнародного інциденту 1978 року в зв'язку 3 падінням радянського супутника «Космос-954» 3 ядерною установкою на борту на територію Канади і забрудненням частини атмосфери і земної поверхні. Канадська сторона в Претензії Радянському Уряду пред'явила вимогу про компенсацію за «шкоду в результаті вторгнення в повітряний простір Канади радянського космічного об'єкта і забруднення території Канади небезпечними радіоактивними відходами. Постраждала сторона в обгрунтування своєї вимоги посилалася, в тому числі, на ст. VII Договору з космосу і п. «а» ст. I Конвенції про відповідальність, заявляючи, що шкода навколишньому середовищу прирівнювалася до шкоди майну. Той же пункт вказаної статті Конвенції про відповідальність був використаний Радянською стороною як головний контраргумент, а саме що завдана шкода екології stricto sensu не підпадала під конвенційне визначення шкоди. Суперечка була в підсумку врегульована дипломатичним шляхом, а питання категоризації шкоди навколишньому середовищу залишилося відкритим ${ }^{3}$.

Слід також зупинити увагу на питанні про порядок відшкодування шкоди та врегулюванні можливих спорів.

Держава, якій завдано шкоди або юридичним чи фізичним особам якої було завдано шкоди, може подати запускаючій державі претензії про компенсацію за таку шкоду (ст. VIII Конвенції про відповідальність).

Претензія щодо компенсації за шкоду подається запускаючій державі дипломатичними каналами. Якщо держава не підтримує дипломатичних відносин з відповідною запускаючою державою, вона може звернутися до іншої держави з проханням подати її претензію цій запускаючій державі або якимось іншим чином репрезентувати ії інтереси. Вона може також подати претензію через Генерального секретаря Організації Об'єднаних Націй за умови, що як держава-позивач, так і запускаюча держава є членами Організації Об'єднаних Націй (ст. IX Конвенції про відповідальність).

Претензію щодо компенсації за шкоду може бути подано запускаючій державі не пізніше, чим через один рік здати заподіяння шкоди або встановлення запускаючої держави, що несе відповідальність за запуск. Проте, якщо державі невідомо про заподіяння шкоди або якщо вона не змогла встановити запускаючу державу, яка несе відповідальність за шкоду, то ця перша держава може подати претензію протягом одного року з дати, коли їй стали відомі вказані вище факти; цей період, проте, в жодному разі не перевищує одного року з дати, коли, за розумними припущеннями, така держава могла взнати про ці факти, доклавши належних зусиль (ст. X Конвенції про відповідальність).

Якщо врегулювання претензії не відбулося дипломатичними переговорами, то сторони можуть створити Комісію з розгляду претензій, яка складається з трьох членів: один призначається позивачем; другий - відповідачем; третій (голова Комісії) - спільно двома сторонами. Якщо сторони

\footnotetext{
${ }^{1}$ Малков, С. П. (2002). Международное космическое право. СПб: СПбГУАП, 165.

2 Волынская, О. А. (2014). Международно-правовые аспекты ответственности в области космической деятельности: диссертация на соискание научной степени кандидата юридических наук. Москва: Российский университет дружбы народов, 53.

${ }^{3}$ Там само, 50.
} 
не можуть спільно обрати голову Комісії, будь-яка 3 них має право звернутися до Генерального секретаря $\mathrm{OOH}$ з проханням призначити таку особу.

Комісія з розгляду претензій встановлює обгрунтованість претензії про компенсацію та визначає суму компенсації, якщо вона підлягає виплаті. Рішення Комісії за домовленістю сторін може бути або остаточним та обов'язковим, або містити визначення рекомендаційного характеру, яке сторони розглядають удусі доброї волі. Таке рішення або визначення повинно виноситися у максимально короткий строк, але не пізніше як через рік з дати іiі створення, якщо вона не вважатиме за необхідне продовжити цей строк. Після винесення рішення чи визначення Комісія передає завірену копію свого рішення чи визначення кожній зі сторін, а також Генеральному секретареві ООН (ст. ХІХ Конвенції про відповідальність).

Якщо шкода, завдана космічним об'єктом, становить у великих масштабах загрозу для життя людей або серйозно позначається на умовах життя населення або діяльності життєво важливих центрів, то держави - учасниці, і зокрема запускаюча держава, вивчають можливість безвідкладного надання відповідної допомоги державі, якій завдано шкоди, коли остання звертається 3 проханням про це. Проте це не зачіпає прав або обов'язків держав - учасниць, що випливають з Конвенції про відповідальність (ст. XXI Конвенції про відповідальність).

Реалізація відповідальності в міжнародному космічному праві будується на системі іiі гарантування. Найчастіше їм виступає страхування. В основному страхування здійснюється юридичними особами та передбачає відшкодування шкоди у визначеній договором страхування сумі. Оскільки шкода, яку завдають в результаті космічної діяльності, може мати катастрофічні наслідки, то, можливо створювати державні фонди, в яких акумулюються кошти, що йдуть на погашення шкоди, що виник в результаті космічної діяльності. У тому випадку, якщо мова йде про співпрацю держав і спільну експлуатацію космічних об'єктів, то фонд може стати міждержавним ${ }^{1}$.

Таким чином, однією з ключових у міжнародному космічному праві $є$ проблема міжнародної відповідальності держав за національну космічну діяльність, хоча на практиці така відповідальність застосовується нечасто.

Слід погодитися з тим, що динамічний розвиток комерційної космічної діяльності пов'язаний 3 активізацією комерційних запусків і розширенням складу комерційних супутникових угруповань на навколоземних орбітах, практично означає підвищений ризик небезпечних зближень і зіткнень функціонуючих апаратів, що, в свою чергу, представляє потенційну небезпеку для життя і здоров'я людей і цілісності майна як в космосі, так і на Землі. Ключовим способом вирішення даної проблеми $€$ створення надійних механізмів міжнародно-правової відповідальності в космічній сфері шляхом посилення чинного в міжнародному космічному праві режиму відповідальності за національну космічну діяльність і за шкоду, завдану в іiї результаті².

Режим міжнародної відповідальності у космічному праві має свої особливості, що визначаються, перед усім, орієнтованістю на потерпілу сторону. Водночас варто наголосити, що існуючий режим відповідальності не у повній мірі відповідає сучасному міжнародному праву, що спричиняє необхідність перегляду існуючих правил, зокрема з огляду на те, що ведення космічної діяльності у більшій мірі здійснюється недержавними акторами, що свідчить про тенденцію комерціалізації космічної діяльності. Важливим при цьому є дотримання балансу між розвитком комерційної космічної діяльності та діяльністю держав із дослідження та використання космічного простору задля забезпечення інтересів людства у цілому.

Розвиток космічної діяльності викликає складнощі при вирішенні питань відповідальності, пов'язані, зокрема, з функціонуванням систем глобальної навігації та супутникових систем, які не можуть бути вирішені через застосування Конвенції про відповідальність 1972 p.

Існують певні неузгодженості режиму відповідальності держав у космічному просторі 3 положеннями міжнародного права навколишнього середовища, зокрема щодо можливості вимагати відшкодування за спричинену серйозну шкоду навколишньому середовищу унаслідок космічної діяльності, а не лише за шкоду, завдану майну держави або іiі громадянам. Необхідним є закріплення

\footnotetext{
${ }^{1}$ Сидорова, Т. Ю. (2004). Ответственность в международном атомном и международном космическом праве: диссертация на соискание научной степени кандидата юридических наук. СПб: Санкт-Петербургский государственный университет, 12.

2 Волынская, О. А. (2014). Международно-правовые аспекты ответственности в области космической деятельности: диссертация на соискание научной степени кандидата юридических наук. Москва: Российский университет дружбы народов, 4.
} 
превентивних заходів для уникнення спричинюваної внаслідок космічної діяльності шкоди, а також застосування ефективних механізмів врегулювання можливих суперечок усфері використання космічного простору за участю різних акторів.

\section{References:}

1. Shemshuchenko, Yu. S., Semeniaka, V. V. (2014). Delimitatsiia povitrianoho i kosmichnoho prostoriv: osnovni teoretychni problemy ta praktyka [Delimitation of airspace and outer space: the basic theoretical problems and practice]. Visnyk Natsionalnoi akademii nauk Ukrainy [Bulletin of the National Academy of Sciences of Ukraine], 11, 18-25. [in Ukrainian].

2. Volynskaja, O. A. (2014). Mezhdunarodno-pravovye aspekty otvetstvennosti v oblasti kosmicheskoj dejatel'nosti [International legal aspects of liability for space activities]: dissertatsiya na soiskaniye nauchnoy stepeni kandidata yuridicheskikh nauk [dissertation for a scientific degree of candidate of legal sciences]. Moscow: Rossiyskiy universitet druzhby narodov. [in Russian].

3. Udalov, D. Je. (2011). Mezhdunarodnoe kosmicheskoe parvo [International space law]. Nauchnyj vestnik MGIIT [Scientific Bulletin of MGIIT], 3, 90-93. [in Russian].

4. Forteau, M. (2010). Space Law. In Crawford J., Pellet A. and Olleson S. (eds.). The Law of International Responsibility. Oxford: Oxford University Press. [in English].

5. Mezhdunarodnoe sotrudnichestvo $v$ ispolzovanii kosmicheskogo prostranstva v mirnyh celjah, 1962 [International co-operation in the peaceful uses of outer space, 1962]. General Assembly of the United Nations. UN Doc. A/RES/I802 (XVII). [in Russian].

6. Deklaratciia pravovykh printcipov, reguliruiushchikh deiatelnost gosudarstv po issledovaniiu i ispolzovaniiu kosmicheskogo prostranstva, 1962 [Declaration of Legal Principles Governing the Activities of States in the Exploration and Use of Outer Space]. General Assembly of the United Nations. UN Doc. RES (XVIII). [in Russian].

7. Lachs, M. (2010). The Law of Outer Space: an Experience in Contemporary Law-Making. Edited by T. MassonZwaan, S. Hobe. Leiden, Boston: Martinus Nijhoff Publishers. [in English].

8. Malkov, S. P. (2002). Mezhdunarodnoe kosmicheskoe pravo [International space law]. St. Petersburg: SPbGUAP. [in Russian].

9. Sidorova, T. Ju. (2004). Otvetstvennost v mezhdunarodnom atomnom i mezhdunarodnom kosmicheskom prave [Responsibility in international nuclear law and international space law]: dissertatsiya na soiskaniye nauchnoy stepeni kandidata yuridicheskikh nauk [dissertation for a scientific degree of candidate of legal sciences]. Saint Petersburg: Saint Petersburg State University. [in Russian]. 